\title{
IS THE LONGLEAF TyPE A CLIMAX?
}

\author{
H.H. Chapman
}

\author{
Yale University School of Forestry
}

What is a climax? The commonly accepted definition is, a type of vegetation which has adapted itself over a long period to a set of environmental conditions, so completely that it is stabilized as long as those conditions remain unchanged.

In a narrower sense, a climax type assumes adaptation to a given set of conditions excluding other conditions. The conditions excluded are those which would usually result in disturbance of this stability or equilibrium. These are: fire, under the conception that fire acts to destroy the stand; insects, when epidemic; destructive winds. The effect of imported diseases and insects, or of man's interference in lumbering, destroys the balance and the type may completely change. Climax types may therefore yield at any time to new conditions to which they are not adapted. Excluding the above factors, there would remain only the climatic and soil factors of site. These factors, isolated from the effects of the so-called destructive group, would finally establish a forest type in which the only surviving species would be those capable of enduring the shade of a forest cover during their establishment. This condition necessitates the elimination of fire, wind, insect epidemics and disease for periods longer than the life span of species which cannot endure shade. When, as with Douglas fir, this span is from 300 to 500 years, and the environmental conditions are such as to create extreme conflagration hazard at intervals of from 3 to 10 years, the establishment of climax types of more shade-enduring species, which are usually inferior in utility, is a pure accident. In the life span of the species, any factor, such as fire, which can be depended on to occur even once within that period, and create conditions favorable to its reproduction, may become the determining factor in its perpetuation as against shade-enduring or so-called climax types. The characteristics of such a relationship are that while fire is required (or its man-made substitute, lumbering) for the removal of the overwood shade and establishment of reproduction, the total exclusion of subsequent fires is equally necessary for survival of this reproduction. The distribution and composition of the forest types in such a region is, therefore, very irregular, much young growth is destroyed prematurely, and here and there a patch may finally attain the climax or shadeenduring type.

If for any reason the normal or natural frequency of fire is increased so that its chance of occurrence on any given area becomes once in 10 to 15 years, the only hope for survival of the tree species is ability to develop a fire resistant bark within such a period and the fact that the fires when they do occur will burn at such times as not to create excessive heat, nor find sufficient fuel to make a blaze destructive to this bark and cambium, and finally, that the crowns of the trees escape fire. These conditions are found, very imperfectly developed, in hardwood species, but most of the southern pines seem well adapted to a fire frequency of this sort. Loblolly, slash, and shortleaf pines, three of the four commercial southern species, rapidly attain a diameter and bark thickness which at 10 years of age enables them to survive the average fire, if it occurs during the winter or early spring and the trees are growing on their normal sites which produce considerable hardwood 
brush or shade and not much coarse sedge grass. But if fires burn at abnormally frequent intervals on such types, as occurs usually after logging, the young reproduction from 10 years and under is apt to be exterminated and the pine replaced by persistently sprouting and more fire resistant oaks.

On such types, it is probable that fire might with advantage be permanently excluded, though there is evidence which indicates that removal of logging slash by fire, in addition to removing this terrific initial hazard, reduces the competition of hardwood brush with pine seedlings not yet started, and thus increases the percentage of pine in the next crop. It must be emphasized, therefore, that a forest type is the form of vegetation which is best adapted to survive not merely a few selected conditions like soil and climate, but all the conditions which will arise over the entire period or span of life of the individual trees of which it is composed.

We must now consider the longleaf pine, Pinus palustris, type of the southern coastal plain. This type constitutes a practically 100 per cent pure stand of a single species. It occupies soils of several types, varying from deep sands to fine silt underlaid by clay or hard pan. These longleaf pine sites do not support a natural growth of the better hardwood species. On the richer grades of soil, rather generally throughout the range of the species, southern red oak, Quercus rubra, is found mixed with the pine and occupying the cut-over land. Another common associate is the black jack oak, $Q$. marylandi$c a$, which is confined to dry sites and is often completely absent from large areas in the more southern portion of the range. On the poorer sites, $Q$. catesbaei, $Q$. cinerea, and Q. geminata are found. These scrub oaks are partial to deep sand and are frequent in Florida. On such sites grass vegetation is sparse.

Throughout most of the northern and western portions of the range of the longleaf pine the natural ground cover is predominantly species of Andropogon or Carex. The presence of legumes is apparently encouraged by occasional burning. Wire grass, Aristida stricta and Muhlenbergia sp., largely takes the place of Andropogon in the more southerly and especially in the eastern portion of the range, in southern Georgia and Florida. In the absence of fire the dead sedge grass or wire grass accumulates into a mat or mulch of dry material which does not decay readily and may be at least six inches thick. Fires run readily in the dead grass on any dry day in winter or spring, summer or fall, even with a single year's accumulation. The fire hazard steadily increases, probably up to the $10^{\text {th }}$ year, and does not diminish thereafter for an unknown period. With the possibility of fire every year, it is extremely probable that even without the aid of man, fires set by lightning might occur in this type as frequently as 3 to 4 years apart and burn over large areas, and, as the type occupies the better drained lands and ridges and is not found in stream bottoms, few continuous natural barriers would intervene.

None of the other southern pines which might grow upon such sites can endure fires of this frequency in their seedling stage, and this reason alone would account for their entire exclusion from the longleaf pine type.

By contrast, the longleaf pine is completely adapted to this frequent fire interval, and has for this reason taken exclusive possession of an area of approximately one-half of the entire coastal plain from Virginia to Texas. As long as the prevailing conditions which created this pure type continue, the longleaf pine type is as truly a climax as the beech-birch-maple type in the northern hardwoods. This conclusion is based on four presumptions of great importance in handling this vast area for forest production: first, that frequent fires at intervals of considerably less than ten years are a natural condition which must be met by any species in order to survive on these sites; second, 
and perhaps more important, that germination and establishment of the seedlings of this fire resistant species is dependent almost absolutely on the occurrence of fire previous to the fall of the seed; third, that fires occurring during the juvenile period previous to the initiation of height growth are necessary for survival in the presence of competing species of pines and hardwoods; and fourth, that fires during the same period may have an important influence in reducing damage from the brown spot disease.

The fire resistance of the longleaf pine has long been evident even to the layman. It is due, first to its habit of concentrating all its growth for an initial period averaging five years in the root and during this time making no height growth; second, to its ability, through food stored in this root, to put out new needles in the spring after the existing foliage has been entirely killed by fire; third, to the protection of its bud or growing point from killing heat, afforded by the dense circular tuft of green needles surrounding this bud; fourth, to its abnormally thick and fire resistant bark as soon as height growth commences; and fifth, to the sparseness of its branching as a young sapling, which discourages crown fires. Remarkable recovery and persistence of growth are shown even in the presence of annual spring fires. An annual fire frequency, however, does not appear to be natural or beneficial. Growth may be stunted and the seedling finally killed. The seedlings germinate and are established in the fall and are destroyed by a fire during that winter or spring unless they happen to grow where the grass cover is thin, when the flames may pass them by, owing to the complete absence of stem and the resultant effectiveness of the protection given to the bud, which is close to the ground and surrounded by a rosette of needles. Up to about 1915 practically no areas of longleaf pine had been purposely protected from fire, and where the species had failed to reproduce itself, the causes were, destruction by hogs, removal of all seed trees, and annual fires, all unnatural and destructive of the normal balance.

It was not until fire protection had been attempted in certain regions that the statistical, scientific evidence became available which has since demonstrated the remaining factors, indicating the dependence of the species on frequent fires for its survival. The conclusion that the species owed its existence and survival to fires and would disappear were it not for the continuance of fire was definitely stated by Mrs. Ellen Call Long in 1888 and by Dr. Roland M. Harper in 1911-13, and this possibility was at least strongly suspected by Sir Charles Lyell in 1849, who stated in his "Second Visit to the United States," (p. 69), in speaking of the vicinity of Tuscaloosa, Alabama, "These hills were covered with longleaved pines, and the large proportion they bear to hardwoods is said to have been increased by the Indian practice of burning the grass; the bark of the oaks and other kinds of hardwoods being more combustible, and more easily injured by fire, than that of the fir tribe. Everywhere the seedlings of the longleaved pine were coming up in such numbers that one might have supposed the ground to have been sown with them; and I was reminded how rarely we see similar self sown firs in English plantations."

At Urania, La. [Louisiana, USA], on the lands cut over for longleaf pine and protected since 1915, the Yale Forest School established over 100 plots in 1917 and following years, on which a detailed record of seedlings, their establishment, survival and growth has been kept. The following relationships were determined in the order mentioned:

1. On land burned annually for many years previous to the fall of seed, abundant seedlings were established, and even under subsequent complete fire protection these seedlings began height growth in the fifth year and developed normally, provided they were free from 
competition of loblolly pine or vigorous oak brush.

2. Wherever other pines or oak germinated or sprouted in the same year, i.e. after the last fire, these competing species, in the absence of further fire, in every case suppressed the longleaf pine and prevented its height growth, ultimately causing its death after about 15 years.

3. On land protected from fire since 1915, new seedlings germinated from seed crops of 1917, 1920 and 1921, 1926 and 1929, but in steadily decreasing numbers. Such seedlings as came up were always found on bare spots or where the radicle could reach mineral soil, and practically never in the unburned dense litter of dead bunch grass or wire grass.

4. The seedlings of the 1917 crop, 2 years after fire protection, came through in many instances and developed normally.

5. The seedlings of the 1921-22 seed crops, 6 to 7 years after fire protection was established, at ten years of age, have failed for the most part to begin their height growth, even when free from all tree and brush competition. They remain stunted and are slowly losing vigor. About the $15^{\text {th }}$ year they will probably die out, though here and there one struggles through.

6. The seedlings of the years 1926 and 1929,11 to 14 years after fire protection was started, seldom survived the first season and failed to establish themselves.

It thus appears that 5 to 6 years of fire protection will so alter the ecological conditions that seedlings if established cannot compete with the sedge and grass vegetation. Continuation of fire protection for 10 years or more prevents, for the most part, the germination and establishment, and cuts short the survival to a period of a year or two, all this in the complete absence of competing brush or tree species.

The dependence of the species on fire for its establishment was shown in still another way. On areas protected from fire and containing numerous seedings both in the grass and in the initial stages of height growth it was noticed in 1922 that a virulent needle blight now designated as the brown spot, Septoria acicola (Thüm) Saccardo, Syl. Fung, 3:507, 1884, attacked and defoliated the pines which had not yet reached a height of over 3 to 4 feet. The foliage beyond this height was not affected, hence the damage was confined largely within the zone that would normally be reached by grass fires. A delicate balance of atmospheric moisture and sunlight appeared to control the infection. The freer movement of air at the greater heights above the ground, and the greater dampness or higher relative humidity near the grass zone and soil surface, thus shaded, appeared to be the favorable factors. The disease did not defoliate or seriously infect young pines when growing under considerable shade. Their later death was from suppression, instead. The infection was worse, apparently, in rainy than in dry seasons. Pines which had started their height growth were killed in three years, but a large percentage of these vigorous saplings escaped. The seedlings in the grass stage were partially defoliated annually where infection was severe, but persisted, in a more and more enfeebled condition, for ten years. There is but little hope of their ultimate survival or recovery but if fires can be kept out long enough, the fate of the seedlings will finally be demonstrated.

The significant fact, however, is that fires have occurred here and there during this period, and in every observed instance, the foliage put forth following the fire was healthy and vigorous and free from the disease dur- 
ing the first season. This release from defoliation by the brown spot enables the seedling to carry this foliage over into the second year. Whenever this happens, a great accretion of vigor is noticed. This is true whether the retention of the foliage be due to absence of fire during the intervening winter or to the disinfection of the area caused by the initial fire.

During the second growing season following a fire, the disease begins to reappear but is not serious. In the third year, it may be very bad again, depending probably on several factors, one of which is the presence of unburned infected areas nearby. So prevalent were fires before the advent of efforts at fire prevention in the South that the existence of this disease was not generally known to land owners until within the last decade, though it was first described in 1884, and was observed by foresters in 1916-18. As it is, the relation of control of the brown spot to the occurrence of fire at intervals of 1 to 3 years is one more evidence of the adaptation of this species to average prevalence of fire at frequent intervals, as an important ecological factor affecting the survival of this forest type.

Efforts to attain absolute fire protection in the longleaf pine and bunch grass type, besides defeating the basic purpose of silviculture, which is the perpetuation of the type, through securing natural reproduction, creates a fire hazard of an alarming character. Fires, if set in this accumulated "rough" during the summer or fall when the ground is dry often kill mature pine and are usually fatal to saplings under 12 inches, which are normally fire resistant. One bad fire, which might be set on any of a hundred days in any year might destroy the forest, while by conforming with natural ecological conditions and burning under control during damp weather, or at night, in the late winter, scarcely a needle would be scorched and the forest would be made safe for the next one or two years.

In the light of these facts the writer suggested ('26) [(Chapman 1926)] that in order to favor the survival of longleaf pine seedlings the ground should be burned in the spring of the fourth year after germination, and again three years after if necessary. (This latter burning was advised as a measure of fire protection for the young saplings, then probably about 5 to 6 feet high.) In the longleaf pine type of the South (and nowhere else in North America to the writer's knowledge) fire at frequent but not necessarily annual intervals is as dependable a factor of site as is climate or soil. The conception of a climax type as one which has reached a stage of permanent equilibrium or perfect adaptation to these constant factors of site should include the longleaf pine type of the South, which presents by far the greatest area and most permanent characteristics of any climax to be found in the United States.

In conclusion, the statements made in this article while based upon continuous and extensive plot records must not be accepted in full as thoroughly established or applying without modification to the entire range of sites and conditions over which the longleaf pine is found. Studies by Paul V. Siggers of the Southern Forest Experiment Station showed that a single fire reduced the brown spot needle disease for the season following the fire, in three cases, respectively, from 61.5 to 21.1 per cent; from 17.8 to 0.2 per cent, and from 16.6 to 1.3 per cent. In two of these cases, the infection at the end of the second season was as heavy on the burned as on the unburned area, while in the third case it was but one half that on the unburned tract. On the two Roberts plots at Urania, La., annual controlled spring fires, first set in the second spring after the germination of the fall seedlings when the seedlings were 14 months old, did not kill a single seedling during five successive fires, and the loss in a second series of five fires was no greater than that from natural causes, including brown spot disease in the adjoining unburned control plot. Each plot was onefourth acre in size. Effectiveness of the use of fire as a disinfectant for this disease must be at least in part influenced by the thor- 
oughness of the disinfection and the proper procedure indicated would be to burn all longleaf pine areas in the vicinity at the same time. Carefully planned experiments have now been initiated by the U.S. Forest Service and by the writer to test the effects of controlled fires, at intervals of 2 to 3 years, on the survival and development of seedling reproduction of this species. Through these experiments it is hoped that a silvicultural practice may be developed which will duplicate the natural conditions under which the longleaf pine has maintained itself for untold ages over the largest area in America occupied by a pure stand of a single species.

This article was reprinted from the October 1932 edition of Ecology 13(4): 328334. Used by permission of the Ecological Society of America.

\section{LITERATURE CITED}

Andrews, E.F. 1917. Agency of fire in propagation of longleaf pine. Botanical Gazette 64: 497-508. doi: 10.1086/332177

Ashe, W.W. 1894. The forests, forest lands and forest products of eastern North Carolina. North Carolina Geological Survey Bulletin 5: 52-72.

Cary, Austin. 1932. Some relations of fire to longleaf pine. Journal of Forestry 30: 594-601.

Chapman, H.H. 1926. Factors determining natural reproduction of longleaf pine on cut-over lands in La Salle Parish, La. Yale University School of Forestry Bulletin 16.

Chapman, H.H. 1927. The use of fire in regeneration of certain types of forest in India. Journal of Forestry 25: 92-94.

Chapman, H.H. 1932. Some further relations of fire to longleaf pine. Journal of Forestry 30: 602-604.

Greene, S.W. 1931. The forest that fire made. American Forests 37: 583.

Harper, Roland M. 1911. The relation of climax vegetation to islands and peninsulas. Bulletin of the Torrey Botanical Club 38: 515-525. doi: 10.2307/2479382

Harper, Roland M. 1913. Economic botany of Alabama, part 1. Geographical report. Geological Survey of Alabama, Monograph 8.

Hedgcock, George G. 1929. Septoria acicola and the brown spot disease of pine needles. Phytopathology 19: 993-999.

Long, Ellen Call. 1888. Notes on some of the forest features of Florida with items of tree growth in that state. Pages 38-41 in: Proceedings of the 7th Annual Meeting of the American Forestry Congress, December 1888, Atlanta, Georgia, USA.

Lyell, Sir Charles. 1849. Second visit to the United States of North America. Volume 2. Harper and Brothers Publishers, New York, New York, USA.

Mattoon, Wilbur R. 1922. Longleaf pine. US Department of Agriculture Bulletin 1061.

Pinchot, Gifford. 1899. The relations of forests and forest fires. National Geographic Magazine 10: 398.

Schwartz, G. Frederick. 1907. The longleaf pine in virgin forests. J. Wiley \& Son, New York, New York, USA.

Siggers, Paul V. 1932. The brown spot needle blight of longleaf pine seedlings. Journal of Forestry 30: 579-593.

Wyman, Lenthall. 1922. Results from sample plots in southern pines. Experiments. Journal of Forestry 20: 780-787. 